\title{
Diverse everyday information practices in Australian households
}

\author{
Vivienne Waller
}

\begin{abstract}
Qualitative research into the everyday information-seeking practices of eight diverse households in the city of Melbourne, Australia permitted insights into the variability in dynamics around information practices. The current study combines an information practice approach to information-seeking with finer detail on use of the Internet. Rather than treat the Internet as a monolithic entity, this study looks separately at the use of more recent Internet technologies such as social media and Wikipedia. The study examines the type of information that people seek, the ways in which they stay informed and their engagement with a range of information resources. In particular, the study illustrates the enormous disparity in the level of information resources available to participants. It also illustrates the extent to which use of the search engine, Google, has become naturalised within the everyday information practices of some Internet users in Australia. This study indicates that public libraries still have particular importance for more disadvantaged members of the population.
\end{abstract}

\section{Introduction}

In a time of rapid technological change, policy makers and librarians increasingly have to make decisions about future directions related to information provision without a clear understanding of the present. This is difficult when the Internet ten years ago is very different from the Internet now. For example, it is now commonplace to access the Internet through a mobile device (Duggan \& Rainie, 2012; Ewing \& Thomas, 2010; Project, 2012) and just six years after it was launched in 2004, Facebook had become the second most popular website in Australia (Experian Hitwise, 2010a). In less than ten years, Google became the most popular website in Australia with nine out of ten web searches undertaken using Google (Experian Hitwise, 2010b). Both Google and Facebook remain the most popular websites in Australia (Experian, 2013). Wikipedia has also gained prominence as a source of information, stirring debate within the library

\section{Author}

Vivienne Waller is a Lecturer in Sociology at Swinburne University of Technology, Australia

Email: vwaller@swin.edu.au

Received 6 June 2013

Accepted 13 September 2013 
professions about how best to respond (Jennings, 2008; Luyt, Ally, Low, \& Ismail, 2010).

Although the Internet has changed markedly in just a few years, little is known about what this means for the everyday information practices of different types of person. Unlike typical information practice studies as well as most qualitative studies on information-seeking, this study deliberately includes a diversity of social types, including students, professionals and children as well as marginalised social types such as refugees and people with disabilities. In contrast to most information-seeking studies, it combines a holistic approach to informationseeking with finer detail on use of the Internet. Providing context for the activities of research participants, the study details the type of information that people seek, the ways in which they stay informed and their engagement with a range of information resources.

Although the analysis is of the information practices of Australian users, the study has implications for research into information practices in any country. It is situated at the intersection of information practice studies, studies of search engine use and household studies of Internet use and the findings are of particular relevance to policy makers and libraries seeking to serve diverse communities.

\section{Literature Review}

The Internet is now such a significant resource in many people's informationseeking activities that it may be taken for granted that the two go together. However, as the following review shows, while important, studies of the use of the Internet in information-seeking are just looking at one possible part of information practices.

\subsection{Use of the Internet in information-seeking}

There are a range of large-scale quantitative analyses that attempt to address issues related to use of the Internet in information search (for example Bughin et al., 2011; CIBER group, 2008; de Rosa, 2005; Dutton, Helsper, \& Gerber, 2009). A study undertaken by the Pew Internet and American Life Project in 2007 (Wells, 2008) found that almost $60 \%$ of respondents would consult the Internet when they had problems they needed to address. In Britain, two-thirds of people turn to the Internet first when looking for information relating to a professional, school or personal project (Dutton \& Blank, 2011). In Australia, almost threequarters $(73 \%)$ of surveyed Internet users described the Internet as an 'important' or 'very important' source of information (Ewing and Thomas, 2010). These studies make it clear that the Internet has become a major source of information, in part because of its convenience (de Rosa, 2005; Horrigan, 2006). A limitation of these studies is that they tend to treat the Internet as a monolithic entity and so do not provide information on how specific Internet technologies, such as search engines and Wikipedia are used.

Social media, Youtube, forums and iTunes university are other Internet technologies that are only just beginning to receive attention in terms of their use as information resources (for example Hughes, Rowe, Batey, \& Lee, 2012; 
Komito \& Bates, 2011; Pandey, Patni, Singh, Sood, \& Singh, 2010; Panovich, Miller, \& Karger, 2012; Witek \& Grettano, 2012).

The Internet technology that has received the most academic attention is the search engine. In 1995, Internet search engines were known to only a small minority with access to the Internet. By contrast, by 2011 it was estimated that 1.6 trillion searches are conducted worldwide each year (Bughin et al., 2011). The widespread use of search engines has necessitated studies on information-seeking that include a specific focus on search engines (Spink \& Jansen, 2004). There have been many fine-grained studies undertaken on how people use search engines; for example, how their eye travels down a Web page of search results (Bar-Ilan, Keenoy, Yaari, \& Levene, 2007; Jansen \& Resnick, 2006; Kellar, Watters, \& Shepherd, 2007). There are also a range of studies looking at the type of queries people type into search engines (Jansen, Booth, \& Spink, 2008; Jansen \& Spink, 2005; Park, 2009; Rose \& Levinson, 2004; Ross \& Wolfram, 2000; Segev \& Ahituv, 2010; Spink, Wolfram, Jansen, \& Saracevic, 2001; Waller, 2011a; Yu \& Young, 2004). However, few studies look at the use of search engines in the context of everyday life.

Founded in 2001, Wikipedia is now another popular way to find information on the Internet. As of June 2013, Wikipedia contained more than 4.2 million articles in English and more than 100,000 articles in each of 44 languages (Wikipedia, 2013). In America, more than half of Internet users (53\%) use Wikipedia and almost one in five (17\%) users use it on any day (Zickuhr \& Rainie, 2011). In Australia, in April 2009, Wikipedia was the twelfth most visited site on the Internet (Waller, 2011b). However, as with studies of search engines, studies of the place of Wikipedia in information-seeking tend to be limited to students (Biddix, Chung, \& Park, 2011; Colón-Aguirre \& Fleming-May, 2012; Eisenberg, 2009; Kim, Yoo-Lee, \& Sin, 2011; Lim, 2009; Luyt, Zainal, Mayo, \& Yun, 2008) or devoid of context (for example Waller, 2011b).

Hence a gap in the literature has been a lack of scholarly attention to detailed analysis of information seeking in daily life contexts (Julien \& Michels, 2004). The need to analyse information-seeking offline as a context for interpreting online search has long been identified as a research priority (diMaggio, Hargittai, Celeste, \& Shafer, 2004). Waller's (2011a, 2011b) exploratory analyses of the subject of queries entered into Google and Wikipedia raise many questions about people's information seeking needs and practices. For example, does the distribution of topics looked up on Google and Wikipedia reflect the interests of search engine and Wikipedia users or does it reflect the suitability of search engines and Wikipedia for looking up particular types of topic? Do Internet users tend to go to particular trusted Websites for information on health, computing, and contemporary affairs, rather than use a search engine or Wikipedia?

\subsection{Information practices and daily life contexts}

Burnett, Besant and Chatman's (2001) work on small worlds and Jaeger and Burnett's (2010) work on information worlds differ from the literature discussed above in that it looks at information within a social context. Burnett, Besant and Chatman identify the salient elements of information worlds as social norms, 
social types, information value, and information behaviour. The concepts of information value and information behaviour inform the research presented in this paper. However, it was not possible to apply the information worlds framework to this research as the research design deliberately selected for participants across a range of social types, socio-economic status, location, household structure; in other words, across a range of information worlds. It was also not possible to investigate social norms around information-seeking within the constraints of interviewing.

ELIS, the Everyday Life Information-Seeking approach (Agosto \& HughesHassell, 2005; Rieh, 2004; Savolainen \& Kari, 2004; Spink \& Cole, 2001)constitutes a small body of literature that also specifically looks at information-seeking in a daily life context, generally the context of the home, but it is less about social norms than is the work of Burnett, Besant and Chatman (Rieh, 2004; Savolainen, 1995).Information practice studies move beyond ELIS to include information use and information sharing. They look at the everyday practices around seeking, using and sharing information in a non-work context (Savolainen, 2008). This includes looking at daily media habits, such as TV, radio, newspaper, checking email and particular websites. McKenzie (2003) identifies the various modes of gaining information as through active seeking, active scanning, non-directed monitoring or by proxy. By proxy refers to being identified as an information seeker and referred to a source by someone else. This and non-directed monitoring are passive forms of acquiring information which are often ignored in information-seeking studies.

There are, as yet, however, few information practice studies (Savolainen, 2008) and those that exist typically focus on one or two particular social types. For example, Julien and Michels (2004) deliberately look at one individual, McKenzie (2003) focuses on pregnant women, Savolainen (2008) focuses on environmental activists and unemployed people, while Savolainen (1995) focuses on industrial workers and teachers. Hence, Savolainen (2008) has identified the need for research on other types of people. A further limitation of these information practice studies is that they do not differentiate between different Internet technologies such as search engines, Wikipedia, social media and forums, looking instead at 'the Internet".

\subsection{Household studies}

The emphasis on individuals in research on information seeking, including that in information practice studies, neglects the household-level contexts and practices of information seeking. The importance of household level contexts has been recognised in research in Internet use, following a tradition of household studies of media use (Lull, 1988; Morley, 1988; Seiter, 1999; Silverstone \& Morley, 1990).Accordingly Internet use studies such as Bakardjieva (2005) and Green, Holloway et al (2004) investigate households: individuals or groups living together in a private dwelling. This can illuminate some of the social practices surrounding how people obtain information in their daily lives. 


\subsection{Information-seeking studies vs Internet Use studies.}

In the last ten years, there has been a recognised need to find out the implications of this new technology of the Internet. This is probably why, in recent years, studies of Internet use (for example Bakardjieva, 2005; Castells, 2001; Cavanagh, 2007; Dutton, 2005; Selwyn, Gorard, \& Furlong, 2005; Van Dijk, 2006; Wellman \& Haythornthwaithe, 2002) or studies of the use of the Internet in informationseeking (for example Kim, 2009; Knight \& Spink, 2008; Rieger, 2009; Rieh, 2004; Rose \& Levinson, 2004) have predominated over studies of informationseeking in general. While there is research to demonstrate the wide range of information literacy abilities of people who use the Internet (Hargittai, 2010; Hargittai \& Hinnant, 2008; Livingstone \& Helsper, 2007), little research looks at the information practices of both users of the Internet and people who do not or cannot use the Internet. It is important to look at the information practices of this latter group in a country like Australia, where one in five people aged over 15 do not or cannot use the Internet. Moreover, it is those on the lowest incomes who are least likely to use the Internet (Australian Bureau of Statistics, 2011; Ewing \& Thomas, 2010).

As with studies in the tradition of ELIS and information practice, the focus of this study is information-seeking, based on interviews about information needs, information-seeking, Internet use and library use. However, this study departs from both ELIS and information practice studies in two ways; firstly, it looks at households and secondly it examines diversity rather than people who share the same 'information world'.

\section{Methodology}

This project was designed to permit qualitative insights into the variability in dynamics around information practices rather than to produce a comprehensive record of information practices. Eight households were selected and data was collected through conducting semi-structured interviews in participants' homes. A total of nineteen interviews were conducted with household families, individual family members and single householders between October 2009 and April 2010. The purpose of the household interviews was to find out about the sort of information interviewees seek and the ways they go about this.

Household interviews are an established method for this type of research (Lull, 1990; Moores, 1996; Morley, 1986). Interviewing the assembled household enables family members to comment on each other's responses which provides richer data and moderates any tendency by individual family members to misrepresent their activities (Morley, 1988). It also allows the researchers to observe the cultural setting and group interaction within the household (Moores, 1996). The unit of analysis is still the individual, but the household provides a context. Accordingly, household data was collected on the number of and location of computers and the type of Internet connection. The occupation and educational status of adults as well as the age of the children was also recorded. Household interviews lasted for between 40 minutes and 1 hour. The interviews started with participants asked to describe their typical routine and their main hobby or interest. They were then asked to identify incidences when information was 
particularly easy or hard to find. It is very difficult for researchers to get a sense of a person's usual information practices. The approach taken was to ask questions about how people find out information about a particular topic (Hargittai, Fullerton, E, \& Thomas, 2010). Two topical issues were chosen for their potential relevance to all participants, and participants were asked whether they had found out information about these issues and how. The issues were swine flu, a pandemic at the time of research, and global warming, an issue which was, at the time, being hotly debated in the mainstream media. If participants had not found out any information about these issues, they were asked to describe how they would go about finding out information about these issues.

The individual interviews enabled the gathering of more detailed data on the familiarity with, use of and opinion of, different sources of information, including books, search engines, Wikipedia, Social Networking Sites, forums, Twitter, Youtube, TV, radio, iTunes, mobile devices, and public libraries. Individual interviews lasted up to half an hour depending on the interviewee's level of Internet use. In the case of single-person households, the household and individual interviews were combined. All interviews were recorded and transcribed. The qualitative research software NVivo was used to code and organise the data and pseudonyms were assigned to participants.

The sample was a purposive one in that the researchers deliberately sought variation in the individuals and households they chose to interview (Hesse-Biber \& Leavy, 2011). As Table 1 shows, selected households spanned a range of household types, socio-economic status, and location, including participants with a disability and from non-English speaking backgrounds (NESB).

\begin{tabular}{|l|l|l|l|l|l|}
\hline $\begin{array}{l}\text { 19 } \text { individuals } \\
\text { househorate }\end{array}$ & Household type & SES & Location & NESB & Disability \\
\hline $\begin{array}{l}\text { Andy, Sharon } \\
\text { Luke } \\
\text { Mark, } \\
\text { Rebecca }\end{array}$ & $\begin{array}{l}\text { Mother, father, } \\
\text { three children }\end{array}$ & high & $\begin{array}{l}\text { Urban } \\
\text { periphery }\end{array}$ & & \\
\hline $\begin{array}{l}\text { Sally (Neville2) } \\
\text { Nick } \\
\text { Scott } \\
\text { Bella }\end{array}$ & $\begin{array}{l}\text { Mother, father, } \\
\text { three children }\end{array}$ & high & $\begin{array}{l}\text { inner } \\
\text { suburban }\end{array}$ & & \\
\hline $\begin{array}{l}\text { Nicole } \\
\text { Kylie } \\
\text { Lisa }\end{array}$ & $\begin{array}{l}\text { Single mother with } \\
\text { two teenage girls }\end{array}$ & low & $\begin{array}{l}\text { Urban } \\
\text { periphery }\end{array}$ & & \\
\hline $\begin{array}{l}\text { Anita } \\
\text { Ellie }\end{array}$ & $\begin{array}{l}\text { Single mother with } \\
\text { one teenage girl }\end{array}$ & high & $\begin{array}{l}\text { inner } \\
\text { suburban }\end{array}$ & & \\
\hline $\begin{array}{l}\text { Amina } \\
\text { Rachel }\end{array}$ & $\begin{array}{l}\text { Single mother with } \\
\text { four children }\end{array}$ & low & $\begin{array}{l}\text { outer } \\
\text { suburban }\end{array}$ & African & \\
\hline Jose & $\begin{array}{l}\text { Single young man in } \\
\text { boarding house }\end{array}$ & low & $\begin{array}{l}\text { inner } \\
\text { suburban }\end{array}$ & $\begin{array}{l}\text { Southern } \\
\text { European }\end{array}$ & $\begin{array}{l}\text { Mental } \\
\text { health }\end{array}$ \\
\hline Sam & $\begin{array}{l}\text { Single young } \\
\text { woman in group } \\
\text { house }\end{array}$ & low & $\begin{array}{l}\text { inner } \\
\text { suburban }\end{array}$ & & Visual \\
\hline Jane & $\begin{array}{l}\text { Mother, father with } \\
\text { two children }\end{array}$ & high & $\begin{array}{l}\text { inner } \\
\text { suburban }\end{array}$ & & \\
\hline
\end{tabular}

Table 1: Purposive sample of interviewees. 
${ }^{1}$ Socio-economic status - based on educational attainment and occupation

${ }^{2}$ The father Neville was away for work when the interviews were conducted.

${ }^{3}$ Given Amina's limited English, a translator was used in the interview with Amina.

${ }^{4}$ It was not possible to interview the rest of Jane's family.

\section{Findings}

This section highlights the relevant themes arising from the analysis of the interview transcripts. It outlines the type of information that research participants sought, the ways in which they kept informed and the nature of their engagement with a range of information resources. Most of the findings of the present study related to active forms of information-seeking; however, some instances of nondirected monitoring and by proxy (McKenzie 2003) were identified.

\subsection{Information sought}

It was clear that the breadth of information actively sought was associated with the breadth of information resources available, and, in particular, effective access to the Internet. All but one of the households in the study had a home Internet connection. However, two of the adult participants, Jose and Nicole, had only very rudimentary Internet skills and Amina had none at all.

Amina was a refugee from central Africa with three school age children and a baby. She had lived in Australia for four years and had extremely limited English skills. Although she had a home Internet connection, she could not use a computer or access the Internet. She was interested in politics and current affairs but relied on other people for this sort of information. Her translator summarised:

There are lots of things she would love to know, even just things that are happening in the local area, in the State and its hard, because of the language difficulties. And sometimes she'll go to the city and she'll buy newspapers - she can't read, but she leaves them in the house and waits until visitors come to the house who can read and tell her what it is about.

(Amina - through translator)

Jose was from Southern Europe and aged in his twenties. He had been in Australia for thirteen years and was living in a boarding house where there was no Internet connection. Jose could speak and read in basic English. He was not employed at the time of research and not looking for work. Jose needed assistance to use the Internet which he received from librarians at the local library. In general, he navigated his way through daily life by asking other people for the information that he needed. His family, his social security case manager, staff at the neighbourhood house and the local library were his main information resources.

Nicole, a single mother of two teenagers, had left school at the end of Year 10. She worked in retail and could not use the Internet without assistance. She did not want to know how to use it either. The main type of information that she actively sought related to sourcing items for house renovations. She did this through physically visiting shops and warehouses. If she ever wanted information from the Internet, she asked her girlfriends or children to look it up for her. When asked the 
hypothetical question of how she would find out about global warming, Nicole replied:

I'd probably put it in the too hard basket to be truthful and go to the kids "Oh what is global warming?", but I myself probably wouldn't ...(trails off)

(Nicole)

In contrast with Amina, Jose and Nicole, those from high SES (socio-economic status) households were confident in searching the Internet and looked for information on a range of topics in which they were interested. Among these adults, the types of information they sought varied widely from trivia, hobbies, product and travel information, news, social events, recipes to health and history, theoretical concepts and politics. The Internet was the main source of this information.

\subsection{Information resources}

This section surveys the use of a range of information resources available to participants. It illustrates the everyday reliance on search engines, and in particular Google, for information amongst those confident in using the Internet.

\subsubsection{Other people}

The research identified two very different reasons why people may rely on others to find information for them. The first relates to lack of information-seeking skill or lack of trust in one's own information seeking-skills versus trust in others. Amina and Jose had little choice but to rely heavily on other people for finding out information. As mentioned, Amina relied on other people to find out what was going on and saved up lots of questions to ask her social worker on her visits. Jose relied on others, in particular the librarian and his caseworker for all of his information needs. Sam, who was also unemployed, had home Internet access but as she said "I'm legally blind so I can't really access the Internet very well for extended periods". Sam relied on the case worker at the neighbourhood house for some of her information needs.

All of the school aged children relied to some extent on their parents and teachers and, of course, all participants used other people at times as an information resource. Those who had Internet skills, however, tended to use the Internet for much of the information they sought. However, even those with Internet skills relied on others as an information source when these others had direct access to the desired information.

\subsubsection{Local libraries}

Local libraries are potentially an information resource for all Australians. The library was an important information resource for Jose. He borrowed books and, with the librarians help, used the Internet at the local library at least once a month. Amina, however had never been to a library because she found it hard to get there with all of her children. Nicole hadn't been to the library for a few years because she didn't know how to use it and found the librarians unhelpful. 
I haven't been shown how to look up where to find a book down at the library and you just need someone to sit with you and say if you want to look that up, this is where you go, this is how you do it, but they're not like that at this library. So that's always been a big block.

(Nicole)

Nicole's children and Sam, the visually impaired woman, similarly found libraries difficult to use.

In contrast, twelve-year old Rebecca, who was from a high SES family who placed great value on their local library, tried to go to the library "as much as possible". In general, however, the children of the high SES households were familiar with the local library, but seldom went. Several adults in these households claimed that they had previously been regular library users, but that now they tended to turn first to the Internet as a resource when searching for information. The library tended only to be used when the required information could not be found on the Internet.

\subsubsection{Search engines}

When participants who were Internet users were asked the very general question of where they would go on the Internet to find out information, almost all of them, adults and children, without hesitation, replied "Google". Further questioning revealed that actually many participants went directly to particular websites for some sorts of information and a couple of adults and Rebecca were experimenting with the Microsoft search engine, Bing, for some searches. In general, however, a search engine, and not just any search engine, but Google, was the first port of call for Internet users. It was certainly at the forefront of participant's minds as the default starting point for information-searching.

\subsubsection{Wikipedia}

When asked did they use Wikipedia, all of the school children but one, (8 year old Mark) volunteered that Wikipedia entries may be wrong because anyone was allowed to edit the content. About half of the children stated that they tended not to use Wikipedia for this reason. Thirteen year old Nick contrasted what he saw as the dubious status of Wikipedia entries with the accuracy of Google search results. He would look up Wikipedia at home but

When I get to school some of the computers don't work with Wikipedia so I look in Google and it might say something different so then I know that it (Wikipedia)'s been wrong.

(Nick)

Two of the children disliked the length of Wikipedia entries. Lisa complained about "all the writing...there's lots of writing so you have to scan through it and look for what you're looking for".

Ellie had a similar view: 
Well the text is always like really, really, really, really long and it's always like a really weird font. Like you never know if it's true because people edit it and stuff. I just don't really like Wikipedia much.

Amongst the adults, Sally, Anita and Jane, all high SES and with children, were the only ones to use Wikipedia. They used it for specific types of searches, such as quick definitions, acronyms and overviews, although they were each well aware of its limitations. As Jane put it:

Well it's obviously open to sabotage and attack and inaccuracy and so on and that's the nature of the source. I think you have to understand that in order to use it effectively. You have to understand what it is and what it isn't.

\subsubsection{Newer Internet technologies}

Several respondents found Youtube particularly helpful for information on how to do things or how to make things. Fifteen year old Scott was the only one who used forums regularly, using them for information on gaming or technology. None of the participants used iTunes or social networking sites like Facebook to find information.

With the exception of Jane, who was a knowledge worker, those who had mobile phones either didn't think they had Internet access or didn't use it on their mobile phone because of the perceived cost. Hence, Jane was the only one who used a mobile phone to connect to the Internet. She said: "I've only had the iPhone for a few months and I wonder how I ever managed without it'.

Jane had also started to use Twitter to find out information, saying:

Well I tend to use Twitter for things that I know won't be on Wikipedia like I put out a Twitter saying I'm at (suburb). Where is a good place to eat?

Jane also used Twitter to find out information that she needed for her job, inside information that people in her line of work who followed her might know. This was not the sort of information that would be on the Internet or in print; for example, information about what was really going on at a particular company.

\subsubsection{Selection from search results}

Although Google was the default starting place for almost all Internet information-seeking, there were marked variations in participants' skills in selecting from the results. In general, participants showed a lot of faith in Google results. Thirteen year old Kylie explained

I don't know, you just sort of type something in, and then it sort of comes up with it and then you normally just like the first one, it's just there, what you want. 
Eight year old Mark described how he chose which result to look at: "I'd just go to any random ones. I just go 'pick"'.

Eight year old Bella had a slightly more methodical approach:

Normally, they have like a little subparagraph under them. And I read that to see if it is on the right thing and I might go to a few different websites to get what I want.

Sam would click on each link, working her way down the list until she was happy with what she had found.

Some of the high SES adults were more discerning, making their selection according to the type of website. For example, Anita explained:

I would look at the description under each of the webpages. If I felt comfortable with the search terms that I'd used I would probably keep to the first couple of pages but if I wasn't really sure I might go a bit further and scroll past that. So that the description would be part of it but also the web address of the page I would look at too. It might depend on what type of web page it was, whether it was a government one or not it may not influence whether or not I choose it, or you know, and education one or not depending upon what I was looking for.

(Anita)

There were, however, also high SES adults like Sally who placed a lot of trust in Google's algorithm to provide appropriate results:

I probably only would ever go to the first page. I would never go to another page; those ones would be just too far removed if it hasn't come up in the first 10 references.

Although no adults expressed concern about the integrity of Google search results, two adult participants expressed concerns about Google's business activities. Anita volunteered

I think that they're evil and they're going to take over the world laughs... I do feel slightly queasy every time I use it to because every time I use it I'm just kind of perpetuating too its size and so I feel a bit uneasy about that.

(Anita)

Jane confessed:

I know that somewhere in the Google empire there is a complete list of all the searches that I've ever done and that worries me a bit, but not enough to stop me using it. 


\subsection{Staying informed}

Information resources are not just those resources actively turned to when seeking for information. As McKenzie's (2003) work illustrates, in addition to active seeking and active scanning for information, people receive information through non-directed monitoring and by proxy.

The ways in which people stay informed without actively seeking or scanning for information are difficult to identify as they are usually a taken for granted part of a person's life. With the exception of the younger children and the African refugee, Amina, all participants identified the traditional media of the TV, radio or newspapers as important ways in which they kept informed. In order to get more in-depth information about how people kept informed, participants were asked whether they knew about swine flu and how they knew about it. All but eight year old Mark knew about swine flu without having to actively seek for information about it. However, the range of ways in which participants had been informed about swine flu illustrated vast disparities in participants' ability to keep informed about what was going on.

Anita, Andy and Sally were actively informed about swine flu, the closest example in the study to what McKenzie (2003) refers to as receiving information "by proxy". Each of them had each received a number of emails from their workplace informing them about the swine flu. Sharon had seen a poster at the doctors and Jose had been told about it by his doctor. Apart from eight year old Mark and the African refugee Amina, all adults and children had heard about swine flu on the radio or TV or read about it in the newspaper. By contrast, Amina had inferred from visual images that there was a contagious epidemic of some sort. Her translator explained that Amina understood about swine flu

By pictures on the news and papers, and especially when she saw pictures of people wearing masks. Then she understood that it is not something good, and then later, just a bit of English and she heard that it's not that serious that it is somewhere in America or other countries, but she understood it, especially with the people covering their mouths.

(Amina - through translator)

\subsection{The importance of the social context of search}

The qualitative nature of the research has enabled the findings on information needs and information resources to be situated within the social context of participants' lives. An example emerged from the research illustrating that even for the same object of inquiry these differences in context may be stark. Both nine year old Luke and Amina, a refugee, needed to find out information about the Red Cross. For Luke this information was part of a school project and he found it very easy to access the information he needed from the Red Cross website. In contrast, Amina just needed to find the location of the Red Cross in Melbourne, as she was desperate for news about her son, from whom she had been separated for ten years. Whereas Luke easily navigated to the Red Cross website, Amina travelled more than 20 kilometres into Melbourne's central business district and stopped people on the street to ask in broken English for directions to the Red 
Cross office. It took several visits like this into the central business district before she was able to successfully locate the Red Cross office.

\section{Discussion}

\subsection{Google - the trusted starting point of internet search}

The study indicates the prominence of search engines, and in particular, Google, in information-seeking amongst the Internet users in this sample. In his study of the information practices of industrial workers and teachers, Savolainen (2008) found that the industrial workers tended to go for the most easily accessible information, even if it was not optimal; in Savolainen's study, this meant friends and contacts. This tendency to go for the most easily accessible information was also evident in this study, but in this case, for Internet users, the information source was not other people, but Google and it was not just a lower educated social type that turned to Google. Savolainen found that the preferred source varied according to the specific nature of the problem and this was also observed to some extent. However, among Internet users in this study, it appeared that the default starting point for finding out almost anything was Google. This is in stark contrast to Rieh's (2004) findings that general search engines like Google and Yahoo were used as a last resort.

Rieh also found that if her research subjects didn't find what they wanted after their first attempt at Internet searching, they would change search engines rather than search terms. In this study, a few participants mentioned Bing but generally participants would retry a Google search with different search terms. Rieh also identified a two-stage process in searching on the web whereby participants would first try to locate a Web site relevant to the topic they were investigating and then search within that site for the information they wanted. This approach was used by some participants who had particular web pages that they would go to for particular topics. However, participants perceived this as an exception to Google as the typical first port of call. Just as Mager (2012) found in her study of people searching Google for health information, users in this study had highly individual practices with regard to selecting search results.

In this study, a complacency about Google was evident that contrasted with participants attitude towards and use of Wikipedia. While both adults and children were wary of the accuracy of Wikipedia content, there was no evidence of any critical engagement with Google. As Jane and others pointed out, Wikipedia is open to "sabotage and attack and inaccuracy". Even so, Wikipedia has been shown to have a similar number of errors to the Encyclopaedia Brittanica and there is no overall bias (Giles, 2005). In contrast, as the Google founders themselves admit, inherent in Google is a bias towards the needs of advertisers (Brin \& Page, 1998). As many commentators have pointed out, other issues with the integrity of Google search results include censorship and inclusion of sponsored results (Jeanneney, 2007). In the United States, at least, most users can not differentiate between sponsored results and 'organic' results (iProspect, 2006). Even so, participants in the study appeared complacent about the reliability of Google, although some expressed reservations about Google's collection of their 
search data. It appeared that Google was a trusted source in terms of the reliability of the information; Wikipedia was not.

A question asked earlier in the paper was whether the distribution of topics looked up on Google and Wikipedia reflect the interests of search engine and Wikipedia users or whether it reflects the suitability of search engines and Wikipedia for looking up particular types of topic. More research is needed on this topic, but the findings of the study suggest that Google is used to look up pretty much anything while Wikipedia tends to be used for the purpose of quick definitions, acronyms and overviews.

\subsection{The importance of context}

The research indicated the importance of taking the context of search into account when analysing information practices. Transaction log analyses of Internet search terms generally involve the classification of thousands of search terms by topic (for example Park, 2009; Spink \& Jansen, 2004; Waller, 2011a) and automated procedures can classify millions of terms (Beitzel, Jensen, Lewis, Chowdhury, \& Frieder, 2007). The context is, of course, completely lost. An example emerged from the research illustrating how even for the same object of inquiry, in this case, the Red Cross, these differences in context may be stark.

\subsection{Blurring of work and home}

In the past, information-seeking researchers have identified a difference between the information looked for at home and the type of information looked for at school or work (Spink \& Cole, 2001). The current study demonstrated the blurring that can now exist between work and home and school and home. For all of the school aged children, information relating to school work or hobbies had a high priority. The case of Jane, in particular, illustrated the blurring of informationseeking for work and information-seeking to satisfy personal curiosity.

\subsection{The difficulty some participants have in meeting basic information needs}

Jaeger and Burnett define information value as "a world's shared sense of a relative scale of the importance of information, of whether particular kinds of information are worth ones' attention or not" $(2010,35)$. This definition of information value implies that there is a level of choice about whether or not particular kinds of information are worth ones' attention. The research suggested, however, that within some information worlds, attention is focused, through necessity, on very basic information necessary for navigating daily life. The cases of both Jose and Amina illustrated this. The information given value within the information worlds of both Jose and Amina was weighted towards how to access basic services. While Amina also valued information about current affairs and politics, her lack of English meant that she was unable to access this type of information.

\subsection{The significance of the library and other people in information practices of non-Internet users}

The Internet is such a taken-for-granted part of many people's lives that some researchers tend to forget that not everyone can access the Internet. For example, 
Savolainen presumes that "in many cases, easy availability and accessibility of the Internet may be taken as self-evident' $(2008,142)$. The current study made no presumptions about Internet use and the cases of Nicole and Amina demonstrated the importance of not assuming that having a home Internet connection implies effective access. It should be noted, however, that lack of effective Internet access is not necessarily experienced as a problem. For example, Nicole could not use the Internet herself and did not want to, but she had the social networks to find whatever information she needed.

While the study suggested that for some high SES families the Internet may be displacing the local public library as a resource for information, the study also indicated the importance of the local library as an information resource for other groups. Savolainen (2008) found that unemployed people had a preference for organizational sources of information, such as public libraries and welfare agencies, because they often had no alternatives. This was evident in the current study, with Jose, in particular, relying heavily on the public library and his caseworker as information resources.

Kennan and Lloyd (2011) have detailed the importance of organizational sources when refugees are transitioning to living in Australia. Amina, the refugee, however, did not have easy access to organisational sources. She rarely received visits from her caseworker and she could not easily get to the library. The interview with Amina provided some graphic examples of Lloyd et al.'s (2013) claim that those refugees who do not have their everyday information needs met are socially excluded, that is, cannot participate effectively in society (Vinson, 2009).

\section{Conclusion}

The research presented in this paper gives a glimpse into the diverse information practices in Australia. Although not intended in any way to be representative of all Australians, the inclusion of a diverse range of participants enabled the study to illustrate the difference in information practices between those who have effective access to the Internet and those who do not. The study also indicated the stark disparity in level of access to information resources, graphically illustrating the social exclusion that can be associated with lack of access to information resources. This study has indicated the importance that public libraries still have for more disadvantaged members of the population, as well as the decreasing perceived importance for some of those with effective access to the Internet.

With regard to the Internet users in the study, it appeared that use of the search engine, Google, had become naturalised within their everyday information practices. The lack of critical engagement with Google search results that was typical in the study suggest a possible ongoing role for the library with regard to information literacy and search engine use, while the scepticism expressed towards Wikipedia could also, perhaps, be usefully harnessed by librarians (Jennings, 2008).

The differences between some of the information practices described in this study and those in studies conducted less than ten years ago highlight the need for ongoing research that keeps up with the rapid speed of technological change. For 
example, as the use of the mobile phones to access information becomes more widespread, it is critical that studies on information practices remain up to date.

\section{References}

Agosto, D. E., \& Hughes-Hassell, S. (2005). People, places, and questions: Preliminary findings from an investigation of the everyday life information seeking behaviors of urban young adults. Library and Information Science Research, 27(2), 141-163.

Australian Bureau of Statistics. (2011). 8146.0 - Household Use of Information Technology, Australia, 2010-11. Canberra: Australian Bureau of Statistics.

Bakardjieva, M. (2005). Internet society: the Internet in everyday life. London: Sage.

Bar-Ilan, J., Keenoy, K., Yaari, E., \& Levene, M. (2007). User rankings of search engine results. Journal of the American Society for Information Science and Technology, 58(9), 1254-1266.

Beitzel, S., Jensen, E., Lewis, D., Chowdhury, A., \& Frieder, O. (2007). Automatic classification of web queries using very large unlabeled query logs. ACM Transactions on Information Systems, 25(2, Article 9).

Biddix, J. P., Chung, C. J., \& Park, H. W. (2011). Convenience or credibility? A study of college student online research behaviors. Internet and Higher Education, 14(3), 175-182.

Brin, S., \& Page, L. (1998). The Anatomy of a Large-Scale Hypertextual Web Search Engine. 30(): (1998). WWW7 / Computer Networks, 30(1-7), 107-117.

Bughin, J., Corb, L., Manyika, J., Nottebohm, O., Chui, M., de Muller Barbat, B., \& Said, R. (2011). The impact of Internet technologies: Search: McKinsey Global Institute.

Burnett, G., Besant, M., \& Chatman, E. (2001). Small worlds: Normative behaviour in virtual communities and feminist bookselling. Journal of the American Society for Information Science and Technology, 52(7), 536-547.

Castells, M. (2001). The Internet galaxy. Oxford: Oxford University Press.

Cavanagh, A. (2007). Sociology and the age of the Internet. Berkshire: Open University Press.

CIBER group. (2008). Information behaviour of the researcher of the future. London: University College London.

Colón-Aguirre, M., \& Fleming-May, R. A. (2012). "You Just Type in What You Are Looking For": Undergraduates' Use of Library Resources vs. Wikipedia. Journal of Academic Librarianship. 
de Rosa, C. (2005). Perceptions of libraries and information resources: A report to the OCLC membership. Ohio: OCLC Online Computer Library Center.

diMaggio, P., Hargittai, E., Celeste, C., \& Shafer, S. (2004). Digital inequality: From unequal access to differentiated use. In K. M. Neckerman (Ed.), Social inequality (pp. 355-400). New York: Russell Sage Foundation.

Duggan, M., \& Rainie, L. (2012). Cell Phone Activities 2012.

Dutton, W. H. (2005). Transforming enterprise: The economic and social implications of information technology Cambridge: MIT Press,.

Dutton, W. H., \& Blank, G. (2011). Next Generation Users: The Internet in Britain. Oxford Internet Survey 2011. Oxford: Oxford Internet Institute, University of Oxford.

Dutton, W. H., Helsper, E. J., \& Gerber, M. M. (2009). The Internet in Britain 2009: Oxford Internet Institute, University of Oxford.

Eisenberg, M. B. (2009). How today's college students use Wikipedia for courserelated research. First Monday, 15(3).

Ewing, S., \& Thomas, J. (2010). CCi Digital Futures 2010: The Internet in Australia Melbourne: ARC Centre of Excellence for Creative Industries and Innovation, Institute for Social Research, Swinburne University of Technology.

Experian. (2013). Weekly online trends: Most popular websites. URL: http://www.experian.com.au/hitwise/online-trends.html [accessed 4.6.13]

Experian Hitwise. (2010a). Press release: Facebook leads the charge as Australia's most popular social network site, October 2010. URL:

http://press.experian.com/Australia/Press-Release/facebook-australias-mostpopular-social-network-site.aspx [accessed 24.5.2012]

Experian Hitwise. (2010b). Press release: Google reigns supreme for Australians in the land of search, March 24, 2010. URL: http://www.hitwise.com/au/presscentre/press-releases/google-reigns-supreme-for-australians/ [accessed 18.5.2010]

Giles, J. (2005). Internet encyclopaedias go head to head. Nature, 438(15), 900901.

Green, L., Holloway, D., \& Quin, R. (2004). @ home: Australian family life and the Internet. In G. Goggin (Ed.), Virtual nation: the Internet in Australia (pp. 88101). Sydney: UNSW Press.

Hargittai, E. (2010). Digital na(t)ives? Variation in Internet skills and uses among members of the net generation. Sociological Inquiry, 80(1).

Hargittai, E., Fullerton, F., E, M.-T., \& Thomas, K. (2010). Trust Online: Young Adults' Evaluation of Web Content. International Journal of Communication(4), 468-494.

Hargittai, E., \& Hinnant, A. (2008). Digital inequality: Differences in young adults' use of the Internet. Communication Research, 35(5), 602-621.

Hesse-Biber, S. N., \& Leavy, P. (2011). The practice of qualitative research (2nd ed.). Thousand Oaks: Sage Publications Inc. 
Horrigan, J. B. (2006). The Internet as a Resource for News and Information about Science. Washington: Pew Internet and American Life Project.

Hughes, D., Rowe, M., Batey, M., \& Lee, A. (2012). A tale of two sites: Twitter vs. Facebook and the personality predictors of social media usage. Computers in Human Behavior, 28(2), 561-569.

iProspect. (2006). iProspect search engine user behaviour study April 2006. URL: http://www.iprospect.com/premiumPDFs/WhitePaper 2006 SearchEngineUserB ehavior.pdf [accessed 22.2.2013]

Jaeger, P. T., \& Burnett, G. (2010). Information worlds: Behaviour, technology, and social context in the age of information. Hoboken: Routledge.

Jansen, B. J., Booth, D. L., \& Spink, A. (2008). Determining the informational, navigational and transactional intent of Web queries. Information Processing and Management, 44, 1251-1266.

Jansen, B. J., \& Resnick, M. (2006). An examination of searcher's perceptions of nonsponsored and sponsored links during ecommerce Web searching. . Journal of the American Society for Information Science and Technology, 57(14), 19491961.

Jansen, B. J., \& Spink, A. (2005). How are we searching the World Wide Web? A comparison of nine search engine transaction logs. Information Processing \& Management, 42(1), 248-263.

Jeanneney, J.-N. 1. (2007). Google and the myth of universal knowledge : a view from Europe (T. Lavender Fagan, Trans.). Chicago: University of Chicago Press.

Jennings, E. (2008). Using Wikipedia to teach information literacy. College \& Undergraduate Libraries, 15(4), 432-437.

Julien, H., \& Michels, J. (2004). Intra-individual information behaviour in daily life. Information Processing and Management, , 40(3), 547-562.

Kellar, M., Watters, C., \& Shepherd, M. (2007). A field study characterizing Web-based information-seeking tasks. Journal of the American Society for Information Science and Technology, 58(9), 999-1018.

Kennan, M. A., \& Lloyd. (2011). Settling in: The relationship between information and social inclusion. Australian Academic \& Research Libraries, 42(3), 191-210.

Kim, J. (2009). Describing and predicting information-seeking behavior on the web. Journal of the American Society for Information Science and Technology, 60(4), 679-693. 
Kim, K. S., Yoo-Lee, E., \& Sin, S. C. J. (2011). Social media as information source: Undergraduates' use and evaluation behavior. Proceedings of the ASIST Annual Meeting, 48.

Knight, S. A., \& Spink, A. (2008). Toward a Web search information behavior model. In A. Spink \& M. Zimmer (Eds.), Web Search: Multidisciplinary Perspectives (pp. 209-234). Heidelberg: Springer-Verlag.

Komito, L., \& Bates, J. (2011). Migrants' information practices and use of social media in Ireland: networks and community. Paper presented at the 2011 iConference, Seattle, Washington.

Lim, S. (2009). How and why do college students use Wikipedia? Journal of the American Society for Information Science and Technology, 60(11), 2189-2202.

Livingstone, S., \& Helsper, E. J. (2007). Gradations in digital inclusion: Children, young people and the digital divide. New Media \& Society, 9(4), 671-696.

Lloyd, A., Kennan, M., Thompson, K., \& Qayyum, A. (2013). Connecting with new information landscapes: information literacy practices of refugees. Journal of Documentation, 69(1), 121 - 144.

Lull, J. (1990). Inside family viewing: Ethnographic research on television's audiences. London: Routledge.

Lull, J. (Ed.). (1988). World families watch television. California: Sage.

Luyt, B., Ally, Y., Low, N. H., \& Ismail, N. B. (2010). Librarian perception of Wikipedia: Threats or opportunities for librarianship? Libri, 60(1), 57-64.

Luyt, B., Zainal, C. Z. B. C., Mayo, O. V. P., \& Yun, T. S. (2008). Young people's perceptions and usage of Wikipedia. Information Research, 13(4).

Mager, A. (2012). Search Engines Matter: From Educating Users Towards Engaging wtih Online Health Information Practices. Policy \& Internet, 4(2), Art 7.

McKenzie, P. J. (2003). A two-dimensional research-based model of information practices. Journal of Documentation, 59(1), 19-40.

Moores, S. (1996). Satellite television and everyday life: Articulating technology. UK: University of Luton Press.

Morley, D. (1986). Family television: cultural power and domestic leisure. London: Comedia Publishing Group.

Morley, D. (1988). Domestic Relations: The framework of family viewing in Great Britain. In J. Lull (Ed.), World Families Watch Television (pp. 22-48). California: Sage. 
Pandey, A., Patni, N., Singh, M., Sood, A., \& Singh, G. (2010). YouTube as a source of information on the H1N1 influenza pandemic. American Journal of Preventive Medicine, 38(3), e1-e3.

Panovich, K., Miller, R., \& Karger, D. (2012). Tie strength in question \& answer on social network sites. Paper presented at the ACM 2012 Conference on Computer Supported Cooperative Work, Seattle, Washington.

Park, S. (2009). Analysis of characteristics and trends of Web queries submitted to NAVER, a major Korean search engine. Library and Information Science Research, 31, 126-133.

Project, T. W. I. (2012) The World Internet Project International Report (third edition). USA: USC Annenberg School Center for the Digital Future.

Rieger, O. (2009). Search engine use behavior of students and faculty: User perceptions and implications for future research. First Monday, 14(12).

Rieh, S. Y. (2004). On the Web At Home: Information Seeking and Web Searching in the Home Environment. Journal of the American Society for Information Science and Technology, 55(8), 743-753.

Rose, D. E., \& Levinson, D. (2004). Understanding user goals in Web search. Paper presented at the WWW 2004, New York.

http://www.medien.ifi.lmu.de/lehre/ws0910/mmi2/literature/UnderstandingUserG oalsInWebSearch_Rose.pdf

Ross, N. C. M., \& Wolfram, D. (2000). End user searching on the Internet: An analysis of term pair topics submitted to the Excite search engine. Journal of the American Society for Information Science, 51(10), 949-958.

Savolainen, R. (1995). Everyday life information seeking: Approaching information seeking in the context of "way of life". Library \& Information Science Research, 17, 259-294.

Savolainen, R. (2008). Everyday information practices. A social phenomenological perspective. Lanham, Maryland: The Scarecrow Press,.

Savolainen, R., \& Kari, J. (2004). Conceptions of the Internet in everyday life information seeking. Journal of Information Science, 30(3), 219-226.

Segev, E., \& Ahituv, N. (2010). Popular searches in Google and Yahoo!: A "digital divide" in information uses? The Information Society, 26(1), 17-37.

Seiter, E. (1999). Television and new media audiences. Oxford: Clarendon Press.

Selwyn, N., Gorard, S., \& Furlong, J. (2005). Whose Internet is it anyway? Exploring adults' (non)use of the Internet in everyday life. European Journal of Communication,, 20(1), 5-26. 
Silverstone, R., \& Morley, D. (1990). Families and their technologies: two ethnographic portraits. In T. Putnum \& C. Newton (Eds.), Household choices (pp. 74-83). London: Futures Publications.

Spink, A., \& Cole, C. (2001). Introduction to the special issue: Everyday life information-seeking research. Library and Information Science Research, 23, 301-304.

Spink, A., \& Jansen, B. J. (2004). Web search: Public searching of the Web. Dordrecht: Kluwer Academic Publisher.

Spink, A., Wolfram, D., Jansen, B. J., \& Saracevic, T. (2001). Searching the Web: The public and their queries. Journal of the American Society for Information Science and Technology, 52(3), 226-234.

Van Dijk, J. (2006). The network society: Social aspects of new media. London: Sage.

Vinson, T. (2009). The origins, meaning, definition and economic implications of the concept social inclusion/exclusion. Department of Education, Employment and Workplace Relations. Canberra. URL: www.socialinclusion.gov.au/sites/default/files/publications/pdf/economicimplications.pdf [accessed 2.5.13]

Waller, V. (2011a). Not just information: Who searches for what on the search engine Google? Journal of the American Society for Information Science and Technology, 62(4), 761-775.

Waller, V. (2011b). The search queries that took Australian Internet users to Wikipedia. Information Research, 16(2).

Wellman, B., \& Haythornthwaithe, C. (2002). The Internet in everyday life. London: Blackwell.

Wells, A. (2008). A portrait of early Internet adopters: Why people first went online - and why they stayed. URL:

http://www.pewinternet.org/pdfs/PIP_Early_Adopters.pdf

Wikipedia (2013).Wikipedia. URL: http://www.wikipedia.org/ [accessed 4.6.13]

Witek, D., \& Grettano, T. (2012). Information literacy on Facebook: An analysis. Reference Services Review, 40(2), 242-257.

Yu, H., \& Young, M. (2004). The impact of Web search engines on subject searching in OPAC. Information Technology \& Libraries, 23(4), 168-180.

Zickuhr, K., \& Rainie, L. (2011). Wikipedia, past and present. URL: http://www.pewinternet.org/ /media//Files/Reports/2011/PIP_Wikipedia.pdf [accessed 7.10.12] 


\section{Acknowledgement}

This work was supported by the Australian Research Council and the State Library of Victoria [LP077215]. The author wishes to thank Dr. Ian McShane for his valuable assistance in conducting the research and the participants for their time.

\section{Open access and copyright}

Library and Information Research is an open access journal. A freely available copy of this paper may be downloaded from the journal's website: http://www.lirgjournal.org.uk/lir/ojs/index.php/lir/index

Copyright and associated moral rights in works published in Library and Information Research are retained by the author(s) but this paper may be used freely, with proper attribution, in educational and other non-commercial settings. 